\section{Survival of Water-stressed Rhododendron Subjected to Freezing at Fast or Slow Cooling Rates}

\author{
Tomasz Anisko and Orville M. Lindstrom \\ Department of Horticulture, University of Georgia, Georgia Experiment \\ Station, GA 30223 \\ Additional index words. cold hardiness, freeze injury, rapid cooling, Rhododendron L. \\ 'Catawbiense'
}

\begin{abstract}
The purpose of the present study was to determine whether water stress affects tolerance of Rhododendron L. 'Catawbiense Boursault' to rapid freezing. Tolerance to freezing at cooling rates of 2 or $6 \mathrm{C} / \mathrm{hour}$ in stems and leaves of plants subjected to continuous and periodic water deficit stresses was examined. Under continuous stress treatments, water content of the growing medium was maintained in a range of 0.60 to 0.75 , 0.45 to 0.60 , or 0.30 to $0.45 \mathrm{~m}^{3} \cdot \mathrm{m}^{-3}$ between $24 \mathrm{Aug} .1992$ and $11 \mathrm{Feb} .1994$. Under periodic stress treatments, water content of the growing medium was maintained near field capacity, i.e., 0.6 to $0.8 \mathrm{~m}^{3} \cdot \mathrm{m}^{-3}$, for the duration of the study or plants were subjected to the periodic stress at various times between $15 \mathrm{July}$ and 19 Feb. during 2 years. Watering of water-stressed plants was delayed until water content reached below $0.4 \mathrm{~m}^{3} \cdot \mathrm{m}^{-3}$, and then was resumed to maintain water content in the range of 0.3 to $0.4 \mathrm{~m}^{3} \cdot \mathrm{m}^{-3}$. Cold hardiness was evaluated in the laboratory with freeze tolerance tests on detached leaves and stem sections. In most cases, cooling at $6 \mathrm{C} /$ hour caused injury at higher temperature than cooling at $2 \mathrm{C}$ /hour. The difference in lethal temperature between the two cooling rates depended on the level of the plant's cold hardiness. In plants cold hardy to about $\mathbf{- 2 5 C}$, freezing at $6 \mathrm{C} / \mathrm{hour}$ caused injury at a temperature $\approx 3 \mathrm{C}$ higher than freezing at $2 \mathrm{C} / \mathrm{hour}$. The effect of cooling rate was not evident in plants cold hardy to about $\mathbf{- 1 8 C}$. Subjecting plants to continuous or periodic water stress did not have an effect on this relationship.
\end{abstract}

Rapid cooling may increase the degree of freezing injury in plants (Chen and Gusta, 1978; Havis, 1964; Haynes et al., 1992; Krasavtsev, 1973; Levitt, 1980; Slater and Warmund, 1986; Steffen et al., 1989; Warrington and Jackson, 1981; White and Weiser, 1964). Freezing plants $>5 \mathrm{C} / \mathrm{h}$ has been classified as rapid cooling (Levitt, 1980). Standard protocols for laboratory freezing tests usually employ cooling rates of 1 to $4 \mathrm{C} / \mathrm{h}$ (Anisko and Lindstrom, 1995; Bray and Parsons, 1981; Burrows et al., 1989; Levitt, 1980; Macdowall and Lowdon, 1989) based on the assumption that faster freezing is uncommon in nature (Levitt, 1980; Palta and Weiss, 1993). Cooling rates exceeding $5 \mathrm{C} / \mathrm{h}$, however, were reported to occur under field conditions (Gross et al., 1991; White and Weiser, 1964). Rapid changes in leaf temperature may be expected to occur, particularly in evergreen plants exposed to sunlight and air temperatures below freezing (Havis, 1964). Under such conditions, a strong absorption of radiant energy may lead to a heating of evergreen foliage beyond air temperature. A difference of 17C between sun-exposed pine needles and the surrounding air was recorded in the absence of

Received for publication 27 Oct. 1995. Accepted for publication 31 Dec. 1995. We sincerely thank Van Veen Nursery of Portland, Ore., for providing plant material for this study. The cost of publishing this paper was defrayed in part by the payment of page charges. Under postal regulations, this paper therefore must be hereby marked advertisement solely to indicate this fact. wind (Tranquillini, 1982). White and Weiser (1964) noted that the foliage of American arborvitae (Thuja occidentalis L.) exposed to sunlight in winter cooled at a rate of $9.5 \mathrm{C} / \mathrm{min}$ at sunset, which led them to conclude that rapid cooling was the cause of observed winter injury.

An increase in cold hardiness induced by water stress has been reported for many plants (Anisko and Lindstrom, 1995; Biddington and Dearman, 1988; Burrows et al., 1989; Chen and Li, 1977; Chen et al., 1975; Gusta et al., 1982; Macdowall and Lowdon, 1989; Paquin, 1977; Thomas and James, 1993; Utsunomiya, 1988; Yelenosky, 1979). It is not known, however, if subjecting plants to water stress can improve their tolerance to rapid freezing.

The purpose of the present study was to determine whether water stress affects tolerance of Rhododendron L. 'Catawbiense Boursault' stems and leaves to rapid (2 vs. 6C/ h) freezing.

\section{Materials and Methods}

Rhododendron 'Catawbiense Boursault' plants were grown for 3 years in an unheated plastic house at the Georgia Station, Griffin. One-year-old plants were potted in 2.2-liter containers the first year of the study and repotted in 9-liter containers the second year. The growing medium (Metro Mix 300; Grace Sierra Horticultural Co., Milpitas, Calif.) contained Canadian sphagnum peat, vermiculite, processed bark ash, and washed sand. Plants were fertilized (1 g.liter $\left.{ }^{-1}\right)$ with Sta-green (11N-
5P-5K; Progress Growers Supply, Canton, Ga.) three times between March and June of each year.

Continuous stress treatments. Plants were grown under three watering regimes between 24 Aug. 1992 and 11 Feb. 1994. Water content of the growing medium was adjusted to be in a range of $\left(\mathrm{m}^{3} \cdot \mathrm{m}^{-3}\right) 0.60$ to 0.75 (wet), 0.45 to 0.60 (medium), or 0.30 to 0.45 (dry). Watering of plants under each regime was discontinued or resumed when the water content reached above or below intended levels, respectively. On several occasions, water content temporarily exceeded target ranges. There were three replications of 10 plants for each watering regime, and the replications were organized in a randomized complete-block design. Replications and their two- and three-way interactions with watering regime and cooling rate were used as an error term.

Periodic stress treatments. Plants were grown under six watering regimes. Water content of the growing medium was either maintained near field capacity, i.e., 0.6 to 0.8 $\mathrm{m}^{3} \cdot \mathrm{m}^{-3}$, for the duration of the study (no stress) or plants under each of remaining five watering regimes were subjected to periodic stress at different times during the year. Drought episodes lasting $\approx 6$ weeks were employed. In 1993-94 and 1994-95, periodic water stress was imposed from 30 Aug. to 9 Oct. (early fall), 9 Oct. to 20 Nov. (late fall), 20 Nov. to 1 Jan. (early winter), and 1 Jan. to 19 Feb. (late winter). In 1994-95, we also used a watering regime with a periodic water stress imposed from 15 July to 30 Aug. (late summer). Watering of the water-stressed plants was delayed until the volumetric water content reached below $0.4 \mathrm{~m}^{3} \cdot \mathrm{m}^{-3}$. Watering was then resumed to maintain water content in the range of 0.3 to $0.4 \mathrm{~m}^{3} \cdot \mathrm{m}^{-3}$. Except for the time of the drought episode intended for each watering regime, plants were watered to near field capacity. There were three replications of three plants for each watering regime, and the replications were organized in a randomized completeblock design.

The volumetric water content of the growing medium was monitored by the timedomain reflectometry technique as described by Anisko et al. (1994). A randomly selected pot in each block $\times$ watering regime was used for monitoring water content of the growing medium.

Cold hardiness of plants was evaluated on 11 Feb. 1994 (continuous stress treatments) and 19 Feb. 1994 and 19 Feb. 1995 (periodic stress treatments) in the laboratory with freeze tolerance tests on detached leaves and stem sections. Leaves and stem sections $\approx 4$ to $5 \mathrm{~cm}$ long were sampled from the terminal shoots of the current-season's growth and pooled for each block $\times$ watering regime. Leaves and stem sections were wrapped in moist cheesecloth, placed in test tubes, and inserted in a freezing bath (Forma Scientific, Marietta, Ohio). Sample temperature was recorded by thermocouples placed next to the stem or leaf. To avoid excessive supercooling of tissue water, when the temperature of the samples stabilized overnight at $-2.0 \pm 0.5 \mathrm{C}$, the samples 
were inoculated with ice crystals. Following freezing of the samples, the temperature was lowered at 2 or $6 \mathrm{C} / \mathrm{h}$. Samples were removed from the bath at $2 \mathrm{C}$ intervals (three leaves and stems for each block $\times$ watering regime) and thawed overnight in the refrigerator at $2.0 \pm$ $0.5 \mathrm{C}$. Control samples were kept on ice for the duration of the test. To evaluate injury, thawed samples were placed in polyethylene bags and incubated at room temperature for 7 days. Freezing injury was evaluated visually with oxidative browning as the criterion and rated on the scale $0=$ no browning, $1=$ browning light or in small areas, $2=$ browning darker or in larger areas, and $3=$ all sample dark brown. The Richards function (von Fircks and Verwijst, 1993) was fitted to the rating values by the modified Gauss-Newton method using the NLIN procedure of SAS (SAS Institute, 1985). The inflection point of the Richards function was used as an estimate of the lethal temperature (von Fircks and Verwijst, 1993). Analysis of variance was performed on the estimates of the lethal temperature to test the effect of watering regimes on cold hardiness. Comparisons between means were conducted using Tukey's Studentized range test.

\section{Results and Discussion}

Continuous stress treatments. The main effect of watering regime on lethal temperature was significant for leaves $(P<0.01)$ and stems $(P<0.01)$ (Fig. 1). The main effect of cooling rate was significant for stems $(P<$ $0.01)$, but not leaves $(P=0.06)$. An interaction between watering regime and cooling rate was significant for leaves $(P<0.01)$ and stems $(P$ $=0.02$ ). Leaves of plants under the medium watering regime had the greatest cold tolerance when cooled at either 2 or $6 \mathrm{C} / \mathrm{h}$ rate. Leaves of plants under the dry regime were the least cold tolerant, and those of plants under the wet regime had intermediate cold hardiness at the $2 \mathrm{C} / \mathrm{h}$ cooling rate (Fig. 1A). The difference between the most and the least cold-hardy leaves was smaller when cooled at $6 \mathrm{C} / \mathrm{h}$ than at $2 \mathrm{C} / \mathrm{h}(\approx 3.4 \mathrm{vs} .8 .9 \mathrm{C})$. The lethal temperature for leaves of plants under the medium and wet watering regimes was lower at $2 \mathrm{C} / \mathrm{h}$ than at $6 \mathrm{C} / \mathrm{h}$. In contrast, leaves of plants under the dry regime tolerated a lower temperature when cooled at $6 \mathrm{C} / \mathrm{h}$. A similar relationship was observed in stems (Fig. 1B), but the lethal temperature for stems cooled at either 2 or $6 \mathrm{C} / \mathrm{h}$ did not differ between the medium and wet watering regimes, and the lethal temperature for stems under the dry regime was the same regardless of cooling rate.

Periodic stress treatments. The main effect of watering regime on lethal temperature was significant in 1994 for leaves $(P<0.01)$ and stems $(P<0.01)$ and in 1995 for stems $(P$ $=0.02)$ but not leaves $(P=0.74)$ (Fig. 2$)$. The main effect of cooling rate was significant in 1994 for stems $(P=0.02)$ but not leaves $(P=$ $0.83)$ and in 1995 for both leaves and stems $(P$ $<0.01)$. The interaction between watering regime and cooling rate was nonsignificant $(P$ $>0.1)$, except for leaves in $1994(P=0.03)$.

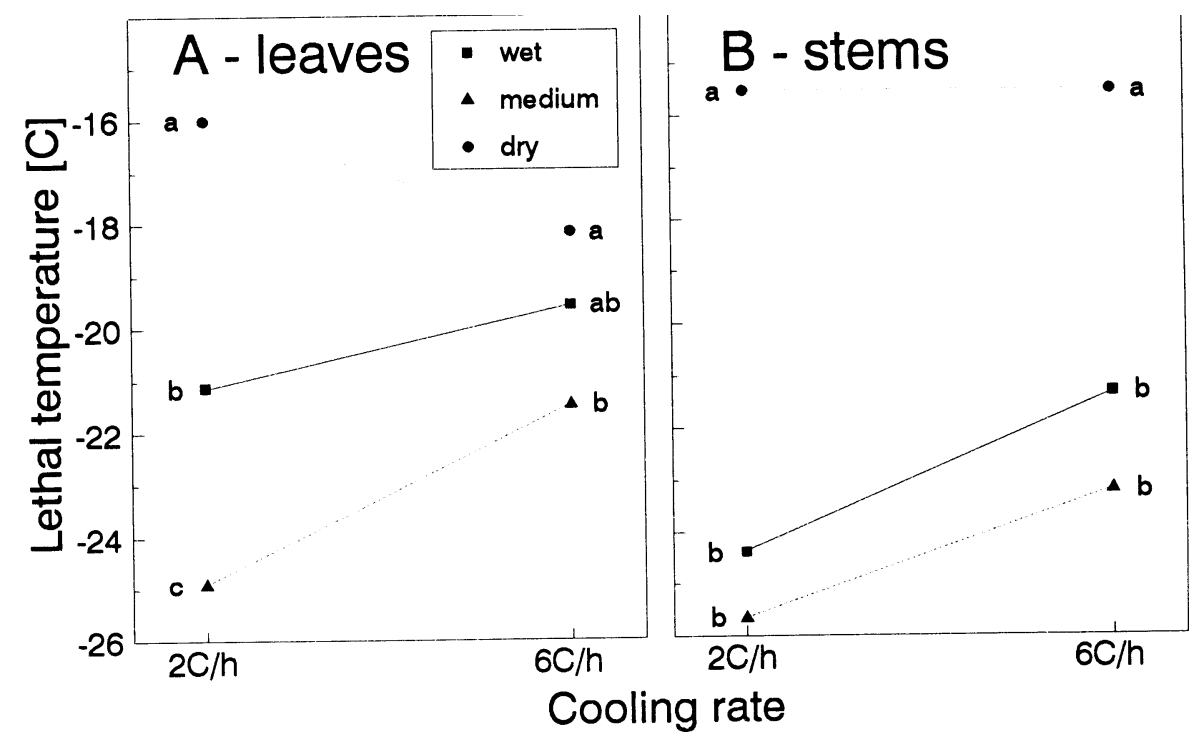

Fig. 1. Lethal temperature for (A) leaves and (B) stems of Rhododendron 'Catawbiense Boursault' plants grown under three watering regimes, subjected to freezing at 2 or $6 \mathrm{C} / \mathrm{h}$ (mean separation between watering regimes by Tukey's Studentized range, at $P=0.05$ ).

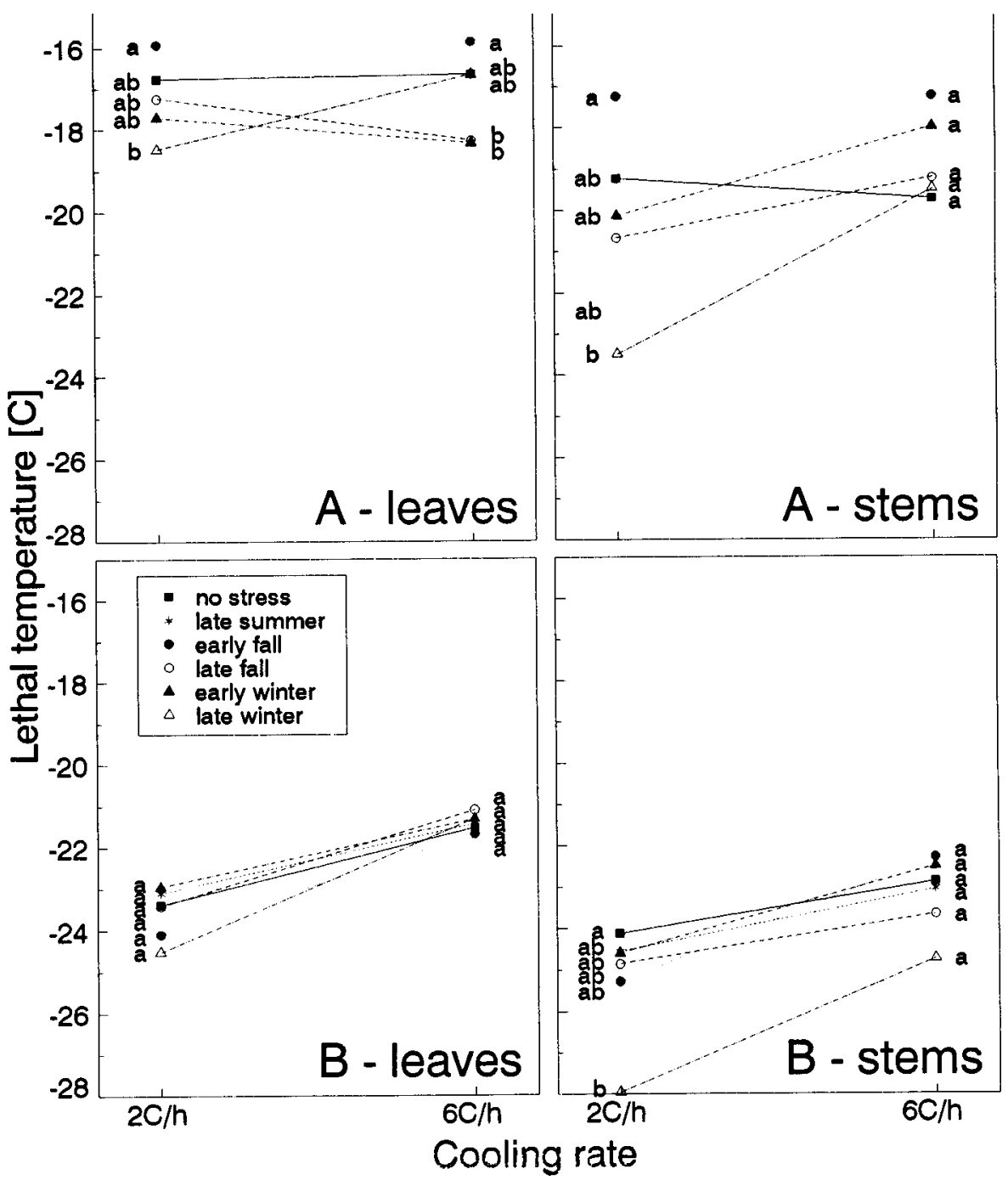

Fig. 2. Lethal temperature for leaves and stems of Rhododendron 'Catawbiense Boursault' plants grown under six watering regimes, subjected to freezing at 2 or $6 \mathrm{C} / \mathrm{h}$ (mean separation between watering regimes by Tukey's Studentized range, at $P=0.05$ ). 
Cold hardiness of leaves and stems of plants under any of the stressful watering regimes was not significantly different from cold hardiness of well-watered plants (no stress) regardless of cooling rate, except for stems of plants under the late-winter watering regime cooled at the rate of $2 \mathrm{C} / \mathrm{h}$ in 1995 (Fig. 2).

In most cases, cooling at $6 \mathrm{C} / \mathrm{h}$ caused injury at higher temperature than cooling at $2 \mathrm{C} /$ $\mathrm{h}$. The difference in lethal temperature between the two cooling rates depended on the level of cold hardiness (Fig. 3). The lower the temperature that plants tolerated, the larger the difference in lethal temperature between the 6 and $2 \mathrm{C} / \mathrm{h}$ cooling rates. When cold hardiness was near the maximum recorded levels (about $-25 \mathrm{C}$ for leaves and about $-28 \mathrm{C}$ in stems), subjecting samples to freezing at $6 \mathrm{C} / \mathrm{h}$ caused injury at $\approx 3 \mathrm{C}$ higher than freezing at $2 \mathrm{C} / \mathrm{h}$. In the present study, the harmful effect of fast freezing was not evident in plants cold hardy to about -18 to $-16 \mathrm{C}$ (Fig. 3). Whether freezing injury of even less cold-hardy plants remains unaffected by cooling rate cannot be inferred from our data. The dependence of the increase in lethal temperature caused by rapid cooling on a plant's cold hardiness agrees with the findings of Haynes et al. (1992). These authors reported 2.5 to $3 \mathrm{C}$ difference in cold hardiness of crape myrtle (Lagerstroemia indica L.) stems cooled at 2 and $6 \mathrm{C} / \mathrm{h}$ in January and March, but they did not detect significant differences between slow and fast cooling in October and August when plants were less cold hardy. Similarly, the difference in cold hardiness of stems of redtip photinia (Photinia $\times$ fraseri Dress 'Birmingham') cooled at 2 and $6 \mathrm{C} / \mathrm{h}$ decreased from $2.5 \mathrm{C}$ in January to $1.9 \mathrm{C}$ in March, and to $1.5 \mathrm{C}$ in August, while the lowest survival temperature of the stems increased from -15.3 to $-12.8 \mathrm{C}$, and $-5.0 \mathrm{C}$, respectively. Apparently, in nonacclimated plants or only partially acclimated plants, factors other than cooling rate (in the 2 to $6 \mathrm{C} / \mathrm{h}$ range tested in the present study) may play an important role and limit plant survival. In fully acclimated plants frozen slowly, the rate of water exchange between the intracellular and extracellular water fractions may be sufficient to prevent intracellular freezing above the lethal temperature. When plants were exposed to rapid freezing, however, injury resulting from intracellular freezing may have occurred at higher temperatures, where the rate of diffusion of water from the cell interior could not keep up with the rate of temperature decline (Krasavtsev, 1973; Levitt, 1980).

The rate of cooling is particularly critical during the initial stages of freezing. Freeze tolerance can be enhanced by progressive dehydration due to migration of water to extracellular spaces during freezing (Larcher, 1982). It is well established that plants cooled slowly to a temperature at which most of the cellular water is frozen extracellularly will tolerate further freezing irrespective of cooling rates (Chen and Gusta, 1978; Harrison et al., 1978; Krasavtsev, 1973; Tyler et al., 1988). Rapid cooling $(15 \mathrm{C} / \mathrm{h})$ of hardened winter wheat (Triticum aestivum L.) led to injury at a higher temperature than slow cooling $(2 \mathrm{C} / \mathrm{h})(\mathrm{Chen}$

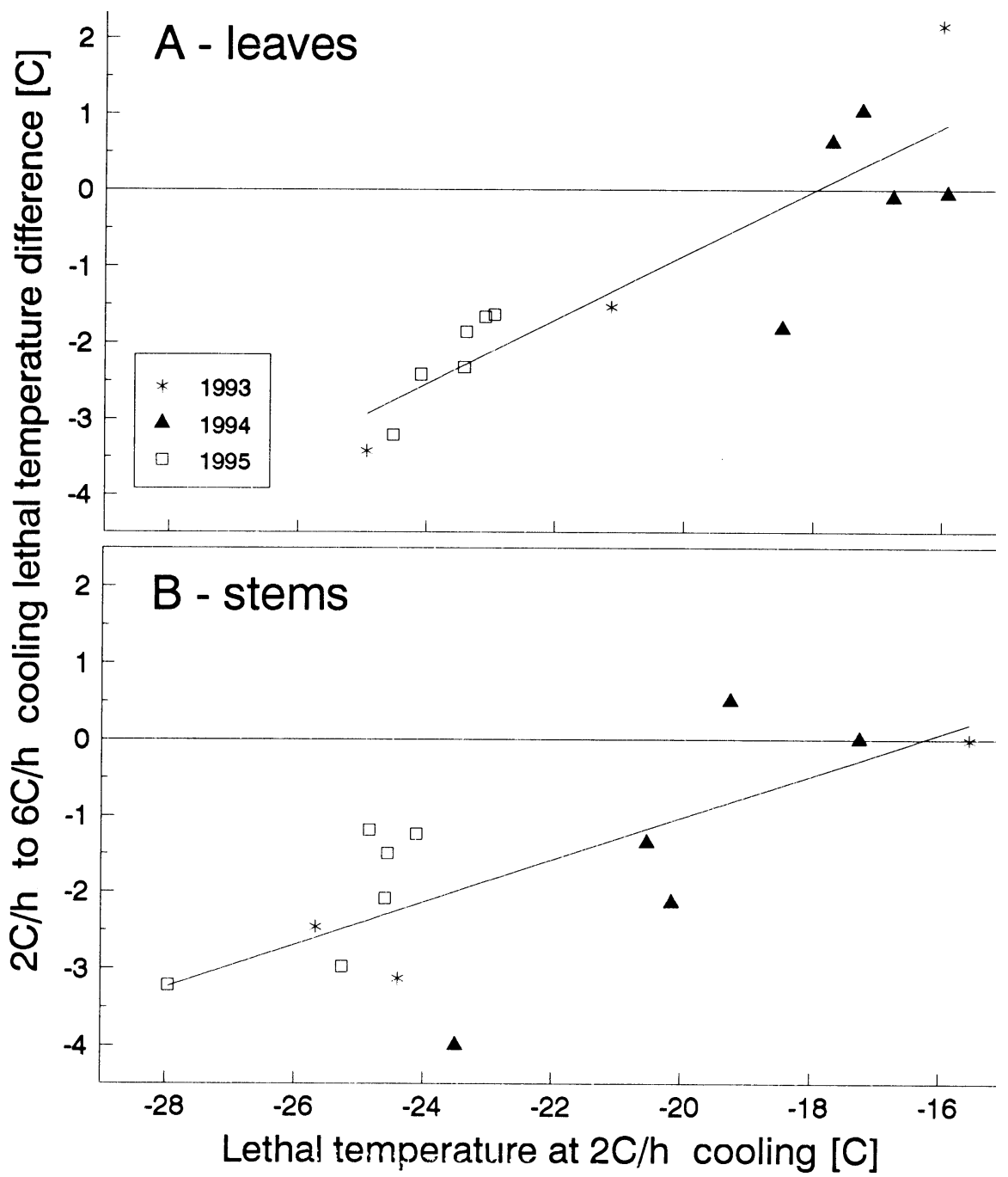

Fig. 3. Relationship between slow $(2 \mathrm{C} / \mathrm{h})$ and fast $(6 \mathrm{C} / \mathrm{h})$ freezing lethal temperature difference and the lethal temperature determined in slow freezing for $(\mathbf{A})$ leaves and $(\mathbf{B})$ stems of Rhododendron 'Catawbiense Boursault' (leaves: $\mathrm{y}=7.56+0.42 \mathrm{x}, R^{2}=0.79$; stems: $\mathrm{y}=4.46+0.27 \mathrm{x}, R^{2}=0.52$ ).

and Gusta, 1978). However, if the plants were first frozen to $-6 \mathrm{C}$ at a slow rate $(2 \mathrm{C} / \mathrm{h})$ and later were frozen at a rapid rate $(15 \mathrm{C} / \mathrm{h})$, the survival temperature remained the same as during slow cooling. Similarly, when fully hardened stems of red-osier dogwood (Cornus sericea $\mathrm{L}$.) were slowly cooled below $-20 \mathrm{C}$, they survived direct immersion in liquid $\mathrm{N}_{2}$ (-196C) (Harrison et al., 1978).

Havis (1964) demonstrated that slowly cooled leaves of 'Catawbiense Grandiflorum' rhododendron tolerated temperatures near $-40 \mathrm{C}$, but were killed when directly exposed to $-18 \mathrm{C}$ at a faster rate of cooling. Havis (1964) noted that allowing leaves to dry at room temperature overnight increased their tolerance to fast freezing. In our study, however, relative differences in cold hardiness between plants grown under various watering regimes were generally unaffected by the cooling rate. Fast cooling rates raised the lethal temperatures for plants that were water-stressed at the time of the freeze test (dry and latewinter watering regimes) in a similar manner as for well-watered plants, or those that had recovered from past water stress.

In summary, this study demonstrated that fast cooling $(6 \mathrm{C} / \mathrm{h})$ raised the lethal temperature in leaves and stems of Rhododendron 'Catawbiense Boursault' compared to slow cooling $(2 \mathrm{C} / \mathrm{h})$. The difference in lethal temperature between slow and fast cooling increased linearly with the level of a plant's cold hardiness. Subjecting plants to continuous or periodic water deficit stress did not have an effect on this relationship.

\section{Literature Cited}

Anisko, T. and O.M. Lindstrom. 1995. Reduced water supply induces fall acclimation of evergreen azaleas. J. Amer. Soc. Hort. Sci. 120:429434.

Anisko, T., D.S. NeSmith, and O.M. Lindstrom. 1994. Time-domain reflectometry for measuring water content of organic growing media in containers. HortScience 29:1511-1513.

Biddington, N.L. and A.S. Dearman. 1988. The effects of mechanically induced stress and water stress on freezing resistance in lettuce and cauliflower seedlings. J. Hort. Sci. 63:609-614.

Bray, E.A. and L.R. Parsons. 1981. Clonal variations in the water relations of red-osier dogwood during cold acclimation. Can. J. Plant Sci. 61:351-363. 
Burrows, R.L., L. Waters, Jr., and A.H. Markhart, III. 1989. Cold acclimation of asparagus seedlings subjected to low temperatures or water stress. HortScience 24:812-814.

Chen, P. and L.V. Gusta. 1978. The role of water in cold hardiness of winter cereals, p. 165-174. In: P.H. Li and A. Sakai (eds.). Plant cold hardiness and freezing stress. Mechanisms and crop implications. vol. 1. Academic, New York.

Chen, P.M. and P.H. Li. 1977. Induction of frost hardiness in stem cortical tissues of Cornus stolonifera Michx. by water stress. II. Biochemical changes. Plant Physiol. 59:240-243.

Chen, P., P.H. Li, and C.J. Weiser. 1975. Induction of frost hardiness in red-osier dogwood stems by water stress. HortScience 10:372-374.

Gross, M., I. Rainer, and W. Tranquillini. 1991. Uber die Frostresistenz der Fichte mit besonderer Berucksichtigung der Zahl der Gefrierzyklen und der Geschwindigkeit der Temperaturanderung beim Frieren und Auftauen. Forstwissenschaftliches-Centralblatt 110:207-217.

Gusta, L.V., D.B. Fowler, and N.J. Tyler. 1982. Factors influencing hardening and survival in winter wheat, p. 23-40. In: P.H. Li and A. Sakai (eds.). Cold hardiness and freezing stress. Mechanisms and crop implications. vol. 2. Academic, New York.

Harrison, L.C., C.J. Weiser, and M.J. Burke. 1978. Freezing of water in red-osier dogwood stems in relation to cold hardiness. Plant Physiol. 62:899_ 901.

Havis, J.R. 1964. Freezing of rhododendron leaves. Proc. Amer. Soc. Hort. Sci. 84:570-574.

Haynes, C.L., O.M. Lindstrom, and M.A. Dirr.
1992. Cooling and warming effects on cold hardiness estimations of three woody ornamental taxa. HortScience 27:1308-1309.

Krasavtsev, O.A. 1973. Significance of initial freezing temperatures in frost hardiness of plants. Fiziologiya Rastienii 20:24-31.

Larcher, W. 1982. Typology of freezing phenomena among vascular plants and evolutionary trends in frost acclimation, p. 417-426. In: P.H. Li and A. Sakai. Plant cold hardiness and freezing stress. Mechanisms and crop implications. vol. 2. Academic, New York.

Levitt, J. 1980. Responses of plants to environmental stresses. vol. 1. Chilling, freezing, and high temperature stresses. Academic, New York.

Macdowall, F.D.H. and J.A. Lowdon. 1989. Leaf carbon isotopic composition $\left(\delta^{13} \mathrm{C}\right)$ and cold hardiness of wheat in relation to growth temperature and moisture stress. Can. J. Bot. 67:2828-2832.

Palta, J.P. and L.S. Weiss. 1993. Ice formation and freezing injury: An overview on the survival mechanisms and molecular aspects of injury and cold acclimation in herbaceous plants, p. 143176. In: P.H. Li and L. Christersson (eds.). Advances in plant cold hardiness. CRC Press, Boca Raton, Fla.

Paquin, R. 1977. Influence of soil moisture content on frost resistance of alfalfa (Medicago media Pers.). Plant Physiol. 59:S-36. (Abstr.)

SAS Institute. 1985. SAS user's guide. SAS Inst., Cary, N.C.

Slater, J. and M. Warmund. 1986. Effect of cooling rate and preacclimation on phloem supercooling in Vitis. HortScience 21:698. (Abstr.)
Steffen, K.L., R. Arora, and J.P. Palta. 1989. Relative sensitivity of photosynthesis and respiration to freeze-thaw stress in herbaceous species. Plant Physiol. 89:1372-1379.

Thomas, H. and A.R. James. 1993. Freezing tolerance and solute changes in contrasting genotypes of Lolium perenne L. acclimated to cold and drought. Ann. Bot. 72:249-254.

Tranquillini, W. 1982. Frost-drought and its ecological significance, p. 379-400. In: O.L. Lange, P.S. Nobel, C.B. Osmond, and H. Ziegler (eds.). Physiological plant ecology. II. Springer-Verlag, Berlin.

Tyler, N., C. Stushnoff, and L.V. Gusta. 1988. Freezing of water in dormant vegetative apple buds in relation to cryopreservation. Plant Physiol. 87:201-205.

Utsunomiya, N. 1988. Increase in cold hardiness induced by water stress in young Psidiums seedlings. J. Jpn. Soc. Hort. Sci. 57:28-33.

von Fircks, H.A. and T. Verwijst. 1993. Plant viability as a function of temperature stress. Plant Physiol. 103:125-130.

Warrington, I.J. and A.K.H. Jackson. 1981. Injury to radiata pine as influenced by freezing and thawing rate, and low temperature duration. N.Z. J. For. Sci. 11:37-44.

White, W.C. and C.J. Weiser. 1964. The relation of tissue desiccation, extreme cold, and rapid temperature fluctuations to winter injury of American arborvitae. Proc. Amer. Soc. Hort. Sci. 85:554-563.

Yelenosky, G. 1979. Water-stress induced cold hardening of young citrus trees. J. Amer. Soc. Hort. Sci. 104:270-273. 